\title{
MODUS PENYELUNDUPAN NARKOTIKA DAN UPAYA PENANGGULANGANNYA DI LEMBAGA PEMASYARAKATAN KELAS II A DENPASAR
}

\section{Oleh:}

Ni Putu Noni Suharyanti ${ }^{1}$

\begin{abstract}
The emergence of law's fact about convicted criminal who involved in drugs crime case as a certain intention by the government, especially for law enforcer in order to sterilize the prison from the drugs. In Bali, the drugs smuggling into prison is even been occur in prison Class II A Denpasar, which found the kinds of drugs such as marijuana or methamphetamine in prison block. From the investigation of that case, in fact there is a certain modes which is used in order to the drugs can be enter to the prison. Therefore, it is important to study in depth about the drug smuggling and the mitigating effort in Prison Class II A Denpasar. The method which is used empirical law research with descriptive qualitative research. The data consists of primary data and secondary data. The technique of collecting data which is used the document study and interview technique. The technique of determine the sample used "non probability sampling". The result found that mode that is used to smuggling the drug into prison in vary such as : put inside the food, drink, threw the drugs from the outside, send a boy to delivered the food, etc. The effort that has been done by the Prison officer in Class II A Denpasar in mitigating the smuggling drug into prison by optimizes the preventive effort and repressive effort. Preventive effort was tighten the security and pacification in prison's gate, sweeping in convict's room, check every goods accurately which is entered into prison, and etc. However, the repressive effort was reported the smuggling or the convict who involved to the Police officer to get further law process.
\end{abstract}

Key words: drug smuggling, mode, mitigating effort, prison

\section{PENDAHULUAN}

\subsection{Latar Belakang}

Definisisosialkejahatanadalahperilaku anti sosial sebagaimana dikemukakan Robert M. Bohm dan Keith N. Haley yaitu "a typical

Mahasiswa Magister (S2) Ilmu Hukum Universitas Udayana, Denpasar, Bali, Alamat: Jalan Tukad Irawadi Gang 19 X Nomor 8 Panjer, e-mail : nonisuharyanti@ gmail.com. social definition of crime is behaviour that violates the norms of society, or more simply antisocial behaviour"2 (definisi sosial yang khas dari kejahatan adalah perilaku yang melanggar norma-norma masyarakat, atau lebih sederhana perilaku anti sosial). Dewasa ini, kejahatan tumbuh dan berkembang

Robert M. Bohm dan Keith N. Haley, 2007, Introduction to Criminal Justice, McGraw-Hill, New York, h. 31. 
mengikuti dinamika masyarakat dan pembangunan seperti yang diungkapkan oleh H.R Abdussalam dan DPM Sitompul dimana "bertambahnya masyarakat dan gencarnya pembangunan, maka kejahatan akan semakin meningkat". ${ }^{3}$ Muncul dan berkembangnya berbagai bentuk kejahatan dengan berbagai modus operandi atau dimensi baru, tidak terlepas dari pengaruh dinamika masyarakat dan pembangunan, khususnya pembangunan di bidang perekonomian serta ilmu pengetahuan dan teknologi (IPTEK). Pesatnya IPTEK dan semakin mengglobalnya dunia menyebabkan kejahatan yang berdimensi lintas negara (transnational crime) seperti peredaran gelap narkotika semakin kompleks dan tinggi intensitasnya di Indonesia, sehingga permasalahan peredaran gelap narkotika telah menjadi perhatian dunia internasional.

Ketentuan hukum nasional tentang tindak pidana narkotika diatur dalam UU RI No. 35 Tahun 2009 Tentang Narkotika. Pembentukan UU ini dapat dikatakan sebagai salah satu bentuk reformasi di bidang hukum pidana khususnya dalam hal pemberantasan tindak pidana narkotika, karena dianggap lebih kompleks dalam hal pengaturan sanksi pidana, misalnya mengenai ancaman sanksi pidanayang jauh lebih berat jika dibandingkan dengan UU sebelumnya. Meskipun demikian, pada kenyataannya narkotika masih tetap beredar di masyarakat, bahkan dilakukan dengan berbagai modus operandi baru dan canggih oleh para pelakunya.

H.R Abdussalam dan DPM Sitompul, 2007, Sistem Peradilan Pidana, Restu Agung, Jakarta, h. 1.
Apabila dicermati secara mendalam, akar permasalahan meningkatnya intensitas kasus tindak pidana narkotika di Indonesia sebenarnya berawal dari maraknya aktivitas penyelundupan narkotika. Berbagai peristiwa penyelundupan narkotika yang terjadi di Indonesia, membuktikan bahwa saat ini Indonesia sudah menjadi pasar potensial untuk memperdagangkan narkotika. Berbagai jalur transportasi, baik darat, laut, dan udara dimanfaatkan sebaik mungkin oleh pelaku untuk dapat menyelundupkan narkotika ke Indonesia. Para penyelundup narkotika mampu memanfaatkan celah, situasi, dan kondisi di Indonesia, sehingga aparat penegak hukum harus bekerjasama dengan berbagai pihak dalam mencegah dan memberantas secara tuntas masuknya narkotika ke Indonesia.

Bali yang terkenal dengan keindahan wisatanya, saat ini telah menjadi pasar potensial bagi perdagangan gelap narkotika oleh para sindikat narkotika internasional, dikarenakan Bali merupakan daerah strategis dan cukup dikenal sebagai salah satu destinasi wisata terbaik di dunia. Beberapa anggota sindikat narkotika internasional yang tinggal di Bali melakukan kejahatan pencucian uang dari hasil bisnis peredaran gelap narkotika tersebut, sehingga tidak mudah untuk mengungkap jaringan peredaran gelap narkotika karena manajemen dan pendanaannya yang sangat bagus dan sindikatnya yang beroperasi dengan sangat rapi dan rahasia. ${ }^{4}$ Hasil yang diperoleh

4 Maiwa News, 2 Juli 2012, Bali Pasar Potensial Sindikat Narkoba Internasional, tersedia di website http:// berita.maiwanews.com, diakses pada tanggal 14 Februari 2015. 
dari perdagangan gelap narkotika dapat mencapai angka miliaran hingga triliunan rupiah, sehingga bisnis tersebut tentu akan menarik minat banyak orang, mengingat semakin meningkatnya jumlah permintaan (demand) akan narkotika oleh para pengguna atau pengkonsumsi narkotika di Bali. Tingginya angka konsumen narkotika di Bali menyebabkan para pengedar atau bandar narkotika akan menggunakan berbagai cara untuk dapat menyelundupkan narkotika ke Bali.

Berkembangnya tindak pidana narkotika dengan modus operandi yang tinggi dan canggih telah mampu menjangkau berbagai kalangan dan usia, bahkan narapidana yang semestinya menjalani program pembinaan pun ikut terjerumus ke dalam peredaran tersebut, baik itu sebagai penyalahguna maupun pengedar narkotika. Adanya narapidana yang terlibat dalam tindak pidana narkotika membuktikan bahwa Lembaga Pemasyarakatan (Lapas) saat ini dianggap tidak steril lagi dari keberadaan narkotika. Narapidana tidak saja menyalahgunakan atau mengedarkan narkotika di dalam Lapas, akan tetapi telah mampu menjadi seorang pengendali peredaran gelap narkotika dari dalam Lapas dengan bantuan alat komunikasi (handphone), menggunakan tenaga kurir narkotika di luar Lapas untuk membantu melancarkan peredaran gelap narkotika.

Mencermati persoalan di atas, permasalahan narkotika seakan-seakan semakin sulit untuk diberantas, apalagi jika mampu menjangkau narapidana yang berada di dalam Lapas. Lapas yang berada dalam keadaan kelebihan kapasitas (over capacity) adalah pemicu utama terjadinya kasus tindak pidana narkotika di kalangan narapidana. ${ }^{5}$ Berkenaan dengan persoalan over capacity, ada tiga Lapas dan tiga Rutan di Bali yang berada dalam keadaan over capacity yaitu, Lapas Kelas II A Denpasar, Lapas Kelas II B Singaraja, Lapas Kelas II B Tabanan, Rutan Kelas II B Gianyar, Rutan Kelas II B Klungkung, dan Rutan Kelas II B Negara. Lapas Kelas II A Denpasar dengan kapasitas 323 orang tahanan dan narapidana, mengalami over capacity tertinggi dengan jumlah 571 orang, disusul dengan Lapas Kelas II B Tabanan (79 orang), Lapas Kelas II B Singaraja (73 orang), Rutan Kelas II B Negara (52 orang), Rutan Kelas II B Gianyar (40 orang), dan over capacity terendah adalah Rutan Kelas II B Klungkung (16 orang). ${ }^{6}$

Lapas Kelas II A Denpasar sebagai Lapas terbesar di Bali, akan menjadi lokasi penelitian terkait dengan permasalahan mengenai modus penyelundupan narkotika ke dalam Lapas beserta upaya penanggulangannya.Dipilihnya Lapas Kelas II A Denpasar sebagai lokasi penelitian oleh peneliti dikarenakan hampir 50\% tahanan dan narapidananya berasal dari kasus tindak pidana narkotika. Di samping itu, berdasarkan informasi dan data awal yang peneliti peroleh bahwasannya kasus tindak pidana narkotika pernah terjadi di kalangan narapidana Lapas Kelas II A

Achmad Rifai, 2014, Narkoba di Balik Tembok Penjara, Aswaja Pressindo, Yogyakarta, h. 17.

6 SDP, Desember 2014, Data Terakhir Jumlah Penghuni per-UPT Pada Kanwil BaliPeriode Desember 2014, tersedia di website : http://smslap.ditjenpas.go.id, diakses pada tanggal 8 Januari 2015. 
Denpasar, dan beberapa kali percobaan penyelundupan narkotika dengan berbagai modus tertentu digagalkan oleh petugas Lapas Kelas II A Denpasar. Oleh karena itu, pertimbangan-pertimbangan tersebut merupakan acuan atau dasar bagi peneliti dalam menyusun penelitian yang berjudul

"Modus Penyelundupan Narkotika dan Upaya Penanggulangannya di Lembaga Pemasyarakatan Kelas II A Denpasar”.

\subsection{Rumusan Masalah}

Berdasarkan latar belakang masalah dalam penelitian ini, maka rumusan masalah yang dapat dikemukakan dalam penelitian ini yaitu sebagai berikut :

1. Apa saja modus-modus yangdigunakan oleh pelaku untuk menyelundupkan narkotika ke dalam Lapas, dalam kaitannya dengan kasus tindak pidana narkotika yang terjadi di Lapas Kelas II A Denpasar?

2. Apa saja upaya-upaya yang dilakukan oleh Lapas Kelas II A Denpasar dalam menanggulangi penyelundupan narkotika ke dalam Lapas?

\subsection{Tujuan Penelitian}

Adapun tujuan dari dilaksanakannya penelitian ini yaitu :

1. Untuk mengetahui, memahami, dan menganalisis secara mendalam mengenai modus-modus yang selama ini digunakan oleh pelaku untuk menyelundupkan narkotika ke dalam Lapas, khususnya di Lapas Kelas II A Denpasar.
2. Untuk mengetahui, memahami,dan menganalisis secara mendalam mengenai upaya-upaya yang dilakukan oleh Lapas Kelas II A Denpasardalam menanggulangi penyelundupan narkotika.

\section{METODE PENELITIAN}

\subsection{Jenis Penelitian}

Mengenai jenis penelitian, Ronny Hanitijo Soemitro dalam Mukti Fajar ND dan Yulianto Achmad mengemukakan sebagai berikut:

Penelitian hukum dapat dibedakan antara ; penelitian hukum normatif atau penelitian hukum doktrinal, yaitu penelitian hukum yang menggunakan sumber data sekunder atau data yang diperoleh melalui bahan-bahan kepustakaan, dan penelitian hukum empiris atau penelitian hukum sosiologis, yaitu penelitian hukum yang memperoleh datanya dari data primer atau data yang diperoleh langsung dari masyarakat. $^{7}$

Berdasarkan pembagian penelitian hukum di atas, maka penelitian tentang modus penyelundupan narkotika dan upaya penanggulangannya di Lapas Kelas II A Denpasar adalah penelitian hukum empiris, karena penelitian ini berangkat dari pemikiran bahwa Lapas sebagai tempat menjalani pembinaan ternyata tidak luput dari keberadaan narkotika. Hal ini tentu

\footnotetext{
Mukti Fajar ND dan Yulianto Achmad, 2007, Dualisme Penelitian Hukum, Fakultas Hukum Universitas Muhammadiyah, Yogyakarta, h. 109.
} 
akan mengganggu proses pembinaan di dalam Lapas, sehingga ada kesenjangan antara das sollen dengan das sein. Oleh karena itu, penting bagi peneliti untuk mengetahui modus-modus yang digunakan oleh penyelundup narkotika hingga mampu memasukkan narkotika ke dalam Lapas dan upaya-upaya yang dilakukan oleh Lapas Kelas II A Denpasar dalam menanggulangi penyelundupan narkotika tersebut.

\subsection{Sifat Penelitian}

Penelitian mengenai modus penyelundupan narkotika dan upaya penanggulangannya di Lapas Kelas II A Denpasar adalah bersifat deskriptif kualitatif (bukan berupa angka-angka dengan rumus tertentu),yaitusuatupenelitian yangbertujuan untuk menggambarkan mengenai sifatsifat individu, keadaan, maupun hubungan antara variabel satu dengan yang lain dalam hubungannya dengan permasalahan dalam penelitian ini.

\subsection{Data dan Sumber Data}

Data yang dipergunakan dalam penelitian ini meliputi data primer dan data sekunder. Adapun sumber data primer dalam penelitian ini berasal dari hasil wawancara yang mendalam dengan pihak Lapas Kelas II A Denpasar, baik terhadap Kepala Lapas Kelas II A Denpasar, dan beberapa petugas Lapas Kelas II A Denpasar seperti petugas Kesatuan Pengamanan Lembaga Pemasyarakatan (KPLP), petugas di bagian pelaporan dan tata tertib, dan petugas lainnya yang terkait. Data sekunder dalam penelitian ini adalah data yang bersumber dari penelitian kepustakaan, dalam artian data tidak diperoleh secara langsung dari sumber pertamanya, melainkan bersumber dari data-data yang sudah terdokumenkan dalam bentuk bahan-bahan hukum, baik bahan hukum primer maupun bahan hukum sekunder. Adapun data sekunder yang dimaksud yaitu sebagai berikut :

a. Bahan Hukum Primer

Bahan hukum primer terdiri dari beberapa peraturan perundang-undangan yang terkait dengan penelitian ini, yaitu UU RI No. 35 Tahun 2009 Tentang Narkotika, dan UU RI No. 12 Tahun 1995 Tentang Pemasyarakatan.

b. Bahan Hukum Sekunder

Bahan hukum sekunder yang digunakan dalam penelitian ini terdiri dari literatur atau buku-buku hukum dan juga non hukum yang berkaitan dengan penelitian ini, jurnal hukum baik jurnal nasional maupun jurnal internasional, hasil-hasil penelitian, artikel atau karya tulis hukum yang termuat di media internet, dan pendapat para pakar hukum.

c. Bahan Hukum Tersier

Bahan hukum tersier, dimana dalam penelitian ini digunakan juga bahan hukum tersier seperti kamus hukum. Berkaitan dengan kamus hukum, Maureen F. Fitzgerald mengemukakan bahwa "legal dictionaries define legal terms and common words with special legal meaning" (kamus hukum mendefinisikan istilah hukum dan katakata umum dengan arti hukum khusus).

\footnotetext{
Maureen F. Fitzgerald, 2007, Legal Problem Solving : Reasoning, Research, and Writing, Edisi Keempat, LexisNexis, Canada, h. 111.
} 
Oleh karena itu, dalam penelitian ini peneliti menggunakan kamus hukum agar mempermudah dalam mengartikan istilahistilah khusus yang dipergunakan dalam hukum.

\subsection{Teknik Pengumpulan Data}

Adapun teknik pengumpulan data yang digunakan dalam penelitian ini yaitu :

\section{a. Teknik Studi Dokumen}

Teknik studi dokumen merupakan teknik awal yang digunakan dalam setiap penelitian ilmu hukum, baik dalam penelitian normatif maupun penelitian hukum empiris. Teknik studi dokumen ini dilakukan dengan cara mengumpulkan bahan-bahan hukum baik primer, sekunder, dan tersier yang terkait dengan penelitian ini.

b. Teknik Wawancara

Teknik wawancara merupakan salah satu teknik yang sering dan paling lazim digunakan dalam penelitian hukum empiris. Dalam hal ini, peneliti telah menentukan beberapa informan yang dapat menjadi sumber dalam mengkaji permasalahan dalam penelitian ini dengan menggunakan teknik wawancara terstruktur (dengan menggunakan pedoman wawancara (interview guide)) dan wawancara tidak terstruktur. Wawancara dilakukan kepada informan kunci yang meliputi, Kepala Lapas Kelas II A Denpasar atau yang mewakili, petugas keamanan (KPLP) di Lapas Kelas II A Denpasar, petugas bagian pelaporan dan tata tertib di Lapas Kelas II A Denpasar, serta petugas lain yang terkait.

\subsection{Teknik Penentuan Sampel Penelitian}

Teknik sampel (teknik sampling) adalah prosedur yang digunakan oleh peneliti untuk mengumpulkan karakteristik dari suatu populasi, meskipun hanya beberapa orang yang diwawancarainya. ${ }^{9}$ Adapun teknik penentuan sampel yang digunakan dalam penelitian ini adalah teknik non probability sampling, dimana dalam teknik pengambilan sampel ini, tidak semua elemen dalam populasi mendapat kesempatan yang sama untuk menjadi sampel. Bentuk teknik non probability sampling yang digunakan adalah judgmental atau purposive sampling dan snowball sampling. Purposive sampling adalah penarikan sampel dilakukan berdasarkan tujuan tertentu, yaitu dimana sampel dipilih atau ditentukan sendiri oleh peneliti berdasarkan pertimbangan kriteria dan sifat tertentu. ${ }^{10}$ Teknik ini digunakan dalam hal menentukan lokasi penelitian yang relevan dengan permasalahan yang diteliti, seperti Lapas Kelas II A Denpasar. Sedangkan snowball sampling adalah teknik penarikan sampel yang didasarkan pada rekomendasi dari sampel sebelumnya. Sampel pertama yang diteliti ditentukan sendiri oleh peneliti dengan mencari key informan (informan kunci) ataupun responden kunci yang dianggap mengetahui tentang penelitian yang dilakukan oleh peneliti. Adapun informan kunci dalam

H. Zainuddin Ali, 2011, Metode Penelitian Hukum, Sinar Grafika, Jakarta, h.98.

10 Soerjono Soekanto, 2012, Pengantar Penelitian Hukum, Cet. III, Universitas Indonesia, Jakarta (UIPress), (selanjutnya disingkat Soerjono Soekanto I), h. 196. 
penelitian ini meliputi Kepala Lapas Kelas II

A Denpasar dan petugas keamanan (KPLP) Lapas Kelas II A Denpasar.

\subsection{Pengolahan dan Analisis Data}

Teknikpengolahandataadalahkegiatan merapikan data hasil dari pengumpulan data sehingga siap untuk digunakan lalu kemudian dianalisis. Model analisis yang digunakan dalam penelitian ini adalah model analisis data kualitatif. Keseluruhan data-data yang terkait dengan modus penyelundupan narkotika dan upaya penanggulangannya di Lapas Kelas II A Denpasar akan diolah dan dianalisis dengan cara menyusun data secara sistematis dan selektif, kemudian dijabarkan secara deskriptif analitis dalam bentuk uraian-uraian yang disertai dengan penjelasan teori-teori hukum, sehingga nantinya dapat diperoleh gambaran serta kesimpulan yang jelas dari permasalahan yang diteliti.

\section{HASIL DAN PEMBAHASAN}

\subsection{Modus Penyelundupan Narkotika} Dalam Kaitannya Dengan Kasus Tindak Pidana Narkotika yang Terjadi di Lapas Kelas II A Denpasar

Lapas Kelas II A Denpasar adalah salah satu Unit Pelaksana Teknis (UPT) Pemasyarakatan di Bali yang berada di lingkungan Kementerian Hukum dan Hak Asasi Manusia. Lapas Kelas II A Denpasar berlokasi di Jalan Gunung Tangkuban

Perahu, Kerobokan Kelod, Kecamatan

Kuta Utara, Kabupaten Badung, sehingga Lapas Kelas II A Denpasar lebih dikenal oleh masyarakat dengan sebutan Lapas Kerobokan. Pada awalnya, Lapas Kelas II A Denpasar memang berada pada ibukota provinsi yakni di wilayah Pekambingan, Denpasar. Namun pada tahun 1977, gedung Lapas Kelas II A Denpasar mulai dibangun di wilayah Kerobokan. Pada tahun 1983, Lapas Kelas II A Denpasar secara resmi pindah dari wilayah Pekambingan (Denpasar) ke wilayah Kerobokan (Badung) dan mulai difungsikan. Gedung bangunan Lapas Kelas II A Denpasar pada saat itu hanya terdiri dari satu unit gedung kantor, dapur, tower, dan dua unit blok hunian.Lapas Kelas II A Denpasar kemudian semakin berkembang dan jumlah blok hunian semakin bertambah seiring dengan bertambahnya penghuni Lapas, sehingga jumlah bangunan gedung Lapas Kelas II A Denpasar saat ini terdiri dari satu unit kantor, satu unit aula, satu unit dapur, satu unit poliklinik, tiga unit tempat ibadah, sarana lapangan olahraga, dan 14 (empat belas) unit blok hunian.

Sampai dengan periode Desember 2014, jumlah keseluruhan tahanan dan narapidana di Lapas Kelas II A Denpasar adalah 865 orang, dimana 423 orang tahanan dan narapidananya berasal dari kasus tindak pidana narkotika, baik yang dilakukan oleh Warga Negara Indonesia (WNI) maupun Warga Negara Asing (WNA). Over capacity yang dialami Lapas Kelas II A Denpasar menyebabkan tidak ada pengkhususan blok hunian bagi narapidana narkotika. Di samping itu, belum difungsikannya Lapas Khusus Narkotika yang dibangun di Desa Tiga Bangli hingga saat ini, juga menyebabkan tidak adanya blok khusus bagi narapidana narkotika meskipun upaya 
Pemerintah untuksegera mengoperasikan Lapas tersebut masih terus dilakukan.

Berbagai persoalan pun muncul akibat over capacity tahanan dan narapidana di Lapas Kelas II A Denpasar, mulai dari kerusuhan, keributan, perkelahian, higga persoalan tindak pidana narkotika di kalangan narapidana. Berkenaan dengan hal ini, Gerald Leinwald dalam Josias Simon mengemukakan bahwa "persoalan besar penjara (prisons) dan tempat penahanan (jail) adalah overkapasitas serius yang membuat tiap program rehabilitasi menjadi gagal sehingga pengamanan (security) dan keteraturan (order) menjadi perhatian utama, bukan lagi pada pembinaan (corrrection)".11 Segala persoalan yang terjadi di dalam Lapas secara tidak langsung telah mengakibatkan terganggunya pelaksanaan program pembinaan apalagi jika tindak pidana narkotika sudah mampu menjangkau narapidana di dalam Lapas. Kasus tindak pidana narkotika yang melibatkan narapidana Lapas Kelas II A Denpasar tidak hanya dilakukan di dalam Lapas, akan tetapi juga di luar Lapas dengan melakukan pemufakatan jahat bersama pihak lain seperti kurir narkotika di luar Lapas melalui alat telekomunikasi padahal secara tegas telah ditentukan bahwa narapidana dilarang untuk memiliki, membawa, dan/atau menggunakan alat elektronik di dalam Lapas.Namun dalam hal ini, ruang lingkup penelitian akan terfokus pada permasalahan mengenaitindak pidana narkotika di dalam Lapaskarena

A. Josias Simon R, 2012, Budaya Penjara: Pemahaman dan Implementasi, Karya Putra Darwati, Bandung, h. 19-20. pembahasan permasalahan pertama terkait dengan modus penyelundupan narkotika ke dalam Lapas.

Seperti yang telah diungkapkan sebelumnya, bahwa akar permasalahan terjadinya tindak pidana narkotika berawal dari adanya penyelundupan narkotika. Sama halnya dengan kasus narkotika yang terjadi di dalam Lapas, awalnya juga bermula dari penyelundupan narkotika. Penyelundupan tersebut tidak hanya dilakukan oleh narapidana, namun para pengunjung yang datang membesuk narapidana, bahkan oleh oknum petugas Lapas itu sendiri. Beberapa kasus tindak pidana narkotika yang pernah terjadi di kalangan narapidana Lapas Kelas II A Denpasar, menunjukkan betapa canggihnya modus yang digunakan oleh pelaku sehingga mampu menyelundupkan narkotika ke dalam Lapas meskipun telah dilakukan pengawasan dan penjagaan yang ketat oleh petugas. Pemeriksaan dan sweeping pun sudah dilakukan oleh petugas secara rutin, akan tetapi kasus tindak pidana narkotika di Lapas masih sering terjadi.

Kata "modus" diartikan sebagai cara $^{12}$, sedangkan "penyelundupan” berasal dari kata "selundup" yang artinya masuk dengan sembunyi-sembunyi atau dengan cara yang tidak sah. ${ }^{13}$ Penyelundupan berarti perbuatan (hal, cara, dan sebagainya) menyelundup atau menyelundupkan (memasukkan dengan sembunyi-sembunyi atau secara gelap). ${ }^{14}$ Berdasarkan pengertian

J.C.T. Simorangkir, dkk, 2000, Kamus Hukum, Sinar Grafika, Jakarta, h. 99.

13 W.J.S. Poerwadarminta, 2007, Kamus Umum Bahasa Indonesia, Balai Pustaka, Jakarta, h. 1068.

14 Ibid. 
tersebut, maka "modus penyelundupan" dimaknai sebagai perbuatan atau cara untuk memasukkan sesuatu secara tidak sah atau melawan hukum. Oleh karena itu, arti dari "modus penyelundupan narkotika" adalah cara memasukkan narkotika ke tempattempat tertentu secara tidak sah (gelap) atau sembunyi-sembunyi.

Berdasarkan data yang peneliti peroleh, baik melalui hasil penelusuran kasus percobaan penyelundupan narkotika maupun kasus tindak pidana narkotika yang pernah terjadi di kalangan narapidana Lapas Kelas II A Denpasar, bahwa modus yang biasanya digunakan oleh pelaku untuk menyelundupkan narkotika ke dalam Lapas yaitu :

1. Memasukkan narkotika ke dalam makanan, minuman, pakaian, pasta gigi, dan barang kiriman lainnya.

2. Melemparkan narkotika dari luar tembok penjara.

3. Menyembunyikan narkotika di dalam saku celana atau saku baju.

4. Menyembunyikan narkotika di atas plafon blok hunian (penjara).

5. Memasukkan narkotika ke dalam tas atau bingkisan.

Berdasarkan hasil wawancara yang peneliti lakukan dengan Kasi Minkamtib Lapas Kelas II A Denpasar (Bapak Hermanus) pada tanggal 21 Januari 2015, bahwa modus atau cara-cara yang digunakan oleh para penyelundup narkotika ke dalam Lapas beraneka ragam, namun modus baru yang digunakan pelaku saat ini yaitu dengan mengirimkan barang kiriman melalui perantara anak kecil sehingga mampu mengelabuhi petugas. Sampai saat ini, pemeriksaan di pintu masuk Lapas Kelas II A Denpasar masih dilakukan dengan cara manual. Tidak ada detektor narkotika maupun alat lainnya yang dapat mengetahui keberadaan narkotika pada para pengunjung yang masuk maupun barang-barang kiriman kepada narapidana. Hal tersebut sesuai dengan apa yang disampaikan oleh Kepala Kesatuan Pengamanan Lembaga Pemasyarakatan (KPLP) Lapas Kelas II A Denpasar (Bapak Wayan Agus Miarda), yang dalam wawancaranya pada tanggal 21 Januari 2015 mengungkapkan bahwa faktor penyebab masuknya narkotika ke dalam Lapas disebabkan oleh beberapa faktor, seperti :

1. Minimnya sarana dan prasarana penunjang keamanan, seperti tidak

adanya alat-alat yang dapat mendeteksi keberadaan narkotika dan obat-obat berbahaya lainnya, seperti sensor dan mesin X-Ray.

2. Keterbatasan jumlah petugas yang menjaga blok hunian tahanan dan narapidana, sehingga tingkat pengamanan dan pengawasannya menjadi tidak maksimal. Khusus untuk Lapas Kelas II A Denpasar, seluruh blok hanya dijaga oleh tiga orang petugas, sedangkan jumlah tahanan dan narapidana sudah mencapai kurang lebih 900 orang.

Mencermati modus-modus pelaku di atas, bahwa Lapas maupun aparat penegak hukum lainnya harus terus berperan aktif mengupayakan tindakan preventif dan represif untuk menekan atau memutus 
jaringan peredaran gelap narkotika di kalangan narapidana karena apabila terjadi pembiaran, maka akan berakibat pada tidak efektifnya pelaksanaan UU RI No. 12 Tahun 1995 Tentang Pemasyarakatan serta terhambatnya pemberantasan tindak pidana narkotika sebagaimana yang telah ditegaskan dalam UU RI No. 35 Tahun 2009 Tentang Narkotika. Segala jenis tindakan harus terus diupayakan untuk mensterilkan keberadaan narkotika di dalam Lapas. Pengawasan yang lebih melekat, baik yang sifatnya internal maupun eksternal perlu terus dilakukan terhadap setiap kegiatan yang berlangsung di dalam Lapas atau Rutan.

Ketegasan petugas Lapas atau Rutan dalam hal larangan penggunaan alat telekomunikasi seperti telepon seluler (handphone) akan meminimalisir keterlibatan narapidana dalam tindak pidana narkotika.

\subsection{Upaya}

\section{Penyelundupan Narkotika di}

Lembaga Pemasyarakatan Kelas II A Denpasar

Upaya penanggulangan kejahatan pada hakikatnya merupakan bagian integral dari upaya perlindungan masyarakat (social defence) dan upaya mencapai kesejahteraan masyarakat (social welfare). Secara umum, upaya penanggulangan kejahatan meliputi upaya penal (hukum pidana) dan non penal (di luar hukum pidana). Upaya penanggulangan kejahatan melalui jalur penal lebih menitikberatkan pada sifat represif (penindasan atau pemberantasan) sesudah kejahatan terjadi, sedangkan jalur non penal lebih menitikberatkan pada sifat preventif(pencegahan atau penangkalan serta pengendalian) sebelum kejahatan terjadi. G.P Hoefnagels dalam teori penanggulangan kejahatannya mengemukakan bahwa upaya penanggulangan kejahatan dapat ditempuh dengan tiga cara yaitu :

1. Penerapan hukum pidana (criminal law application).

2. Pencegahan tanpa pidana (prevention without punishment).

3. Mempengaruhi pandangan masyarakat mengenai kejahatan dan pemidanaan lewat mass media (influencing views of society on crime and punishment/ mass media). ${ }^{15}$

Terkaitdenganupayapenanggulangan penyelundupan narkotika, Lapas Kelas II A Denpasar tetap mengoptimalkan upaya preventif (pencegahan) dan represif. Berdasarkan hasil wawancara yang peneliti lakukan dengan Kasi Minkamtib Lapas Kelas II A Denpasar (Bapak Hermanus) bahwa untuk menanggulangi masuknya narkotika ke dalam Lapas, petugas secara rutin melakukan inspeksi mendadakan (sidak) dan sweeping ke blok-blok hunian maupun areal Lapas secara rutin dua kali dalam seminggu, namun jika dibutuhkan petugas akan melakukannya setiap hari. Apabila berdasarkan hasil pemeriksaan ditemukan barang bukti berupa narkotika, maka narapidana beserta barang tersebut akan diinterogasi kemudian dilaporkan

\footnotetext{
G. Peter Hoefnagels, 1969, The Other Side of Criminology, h. 16-18 dikutip dari Barda Nawawi Arief, 2011, Bunga Rampai Kebijakan Hukum Pidana (Perkembangan Penyusunan Konsep KUHP Baru), Kencana Prenada Media Group, Jakarta, h. 45.
} 
kepada pihak yang berwajib untuk diproses secara hukum. Namun terkadang ditemukan narkotika tanpa penguasaan seseorang, seperti ditemukan tergeletak di samping tempat sampah atau halaman tertentu sehingga petugaskesulitan untuk melacak siapa pelakunya.Upaya preventif lain yang dilakukan untuk menanggulangi masuknya narkotika yaitu dengan memperketat penjagaan dan pengamanan di pintu masuk (portal) Lapas, serta memeriksa secara saksama setiap barang akan dibawa masuk ke dalam Lapas.

Upaya represif terhadap percobaan penyelundupan maupun penyelundupan narkotika dilakukan dengan melakukan penegakan hukum terhadap pelaku penyelundupan narkotika, baik itu narapidana, pengunjung, maupun oknum petugas yang terlibat melalui koordinasi dengan pihak yang berwajib. Hal tersebut didasarkan atas ketentuan Pasal 17 Peraturan Menteri Hukum dan HAM No. 6 Tahun 2013 Tentang Tatib Lapas dan Rutan yang secara tegas menyebutkan bahwa "dalam hal pelanggaran yang dilakukan oleh narapidana atau tahanan diduga tindak pidana, Kepala Lapas atau Kepala Rutan meneruskan kepada instansi yang berwenang”. Hal ini sesuai dengan apa yang disampaikan oleh Kepala KPLP Lapas Kelas II A Denpasar (Bapak Wayan Agus Miarda), dimana terkait dengan tahanan dan narapidana yang kedapatan membawa atau memiliki barangbarang terlarang seperti narkotika di dalam Lapas, petugas

Lapas atas perintah Kepala Lapas langsung mengadakan koordinasi dengan pihak yang berwajib tanpa toleransi atau teguran lisan terlebih dulu terhadap tahanan dan narapidana yang diduga melakukan tindak pidana narkotika. Sama halnya dengan para pengunjung Lapas yang kedapatan membawa narkotika, pihak Lapas juga akan langsung mengkoordinasikannya dengan pihak yang berwajib. Setelah melakukan koordinasi, pihak Lapas akan menyerahkan sepenuhnya wewenang kepada pihak yang berwajib untuk melanjutkan proses hukum terhadap pelaku yang bersangkutan.

Upaya penanggulangan kejahatan menggunakan sarana pidana sangat penting untuk mengefektifkan peraturan perundangundangan tentang narkotika, seperti yang diungkapkan oleh Soerjono Soekanto dalam teori penegakan hukum bahwa "penegakan hukum bukan berartipenegakan hukum bukanlah semata-mata berarti pelaksanaan perundang-undangan, namun juga sebagai pelaksanaan keputusan-keputusan Hakim". ${ }^{16}$ Hal serupa diungkapkan oleh Woro Winandi dan Indra Rukmana yaitu "sudah merupakan tugas bagi hukum pidana untuk memungkinkan terselenggaranya kehidupan bersama antar manusia, tatkala persoalannya adalah benturan kepentingan antara pihak yang melanggar norma dan kepentingan masyarakat umum". ${ }^{17}$ Terhadap narapidana yang terbukti melakukan tindak pidana

Soerjono Soekanto, 2012, Faktor-Faktor yang Mempengaruhi Penegakan Hukum, Cet. XI PT RajaGrafindo Persada, Jakarta, (selanjutnya disebut Soerjono Soekanto II), h. 7.

17 Woro Winandi dan Indra Rukmana Lukito, Penjatuhan Pidana Mati Dalam Tindak Pidana Narkoba, Jurnal Hukum Vol. XIX, No. 19, Edisi Oktober 2010, Fakultas Hukum Universitas Narotama Surabaya, h. 1. 
narkotika, disamping diproses secara hukum juga akan menerima sanksi administrasi berupa hukuman disiplin karena dianggap telah melanggar peraturan tata tertib Lapas. Oleh karena tindak pidana narkotika dikategorikan sebagai pelanggaran berat, maka narapidana yang bersangkutan dapat dijatuhi hukuman disiplin tingkat berat, baik berupa tutupan sunyi paling lama enam hari atau peniadaan hak-hak tertentu dalam jangka waktu tertentu sesuai dengan peraturan perundang-undangan yang berlaku (remisi, pembebasan bersyarat, asimilasi, cuti bersyarat, cuti mengunjungi keluarga, dan hak yang lainnya). Dalam memberikan tindakan disiplin atau menjatuhkan hukuman disiplin, petugas pemasyarakatan wajib memperlakukan narapidana yang bersangkutan secara adil dan tidak bertindak sewenang-wenang serta mendasarkan tindakannya pada peraturan tata tertib Lapas yang berlaku.

\section{SIMPULAN DAN SARAN \\ 1. Simpulan}

Berdasarkan latar belakang, rumusan masalah yang diperoleh, serta pembahasan yang dilakukan, maka simpulan yang dapat dikemukakan dari hasil penelitian ini yaitu sebagai berikut :

1. Penyelundupan narkotika ke dalam Lapas Kelas II A Denpasar selama ini tidak hanya dilakukan oleh narapidana, tetapi para pengunjung yang datang membesuk narapidana, bahkan pernah dilakukan oleh oknum petugas Lapas itu sendiri. Modus yang digunakan dalam penyelundupan narkotika beraneka ragam, mulai dari memasukkan narkotika ke dalam makanan, minuman, pakaian, pasta gigi, dan barang kiriman lainnya, menyembunyikan narkotika di dalam saku baju atau celana, di atas plafon blok hunian (penjara), melemparkan narkotika dari luar tembok penjara, dan memasukkan narkotika ke dalam tas atau bingkisan.

2. Penanggulangan terhadap penyelundupan narkotika oleh Lapas Kelas II A Denpasar dilakukan dengan mengoptimalkan upaya preventif dan represif. Upaya preventif dilakukan dengan mengadakan sweeping atau razia secara rutin di dalam blok hunian (penjara) maupun areal Lapas, memperketat pengawasan, penjagaan, dan pengamanan di pintu masuk (portal) Lapas, dan memeriksa secara saksama setiap barang kiriman yang akan dibawa masuk ke dalam Lapas. Upaya represif dilakukan dengan berpartisipasi aktif dalam hal pelaporan terkait adanya dugaan tindak pidana narkotika di dalam Lapas. Setiap pelaku yang diduga melakukan tindak pidana di dalam Lapas akan dilaporkan kepada pihak yang berwajib, untuk diproses secara hukum.

\section{Saran}

1. Kepada Lapas, diharapkan agar terus berpartisipasi aktif dan bekerjasama dalam menanggulangi tindak 
pidana narkotika mengingat modus penyelundupan narkotika saat ini yang semakin canggih. Di samping itu, penambahan personel petugas keamanan di Lapas diharapkan relevan dengan jumlah tahanan dan narapidana, sehingga dapat mengoptimalkan pengawasan di dalam Lapas.

2. Kepada Pemerintah, diharapkan agar selalu mengupayakan strategi untuk mencari solusi atas permasalahan over capacity di Lapas dan Rutan, karena persoalan over capacity secara tidak langsung akan menimbulkan dampak negatif yang akan mengganggu pelaksanaan program pembinaan kepada narapidana. Ketersediaan alatalat yang dapat mendeteksi keberadaan narkotika, seperti detektor narkotika dan X-Ray juga sangat diperlukan untuk mencegah masuknya narkotika ke dalam Lapas.

\section{DAFTAR PUSTAKA}

\section{A. BUKU}

Abdussalam, H.R, dan DPM Sitompul, 2007, Sistem Peradila Pidana, Restu Agung, Jakarta.

Ali, H. Zainuddin, 2011, Metode Penelitian Hukum, Sinar Grafika, Jakarta.

Arief, Barda Nawawi, 2011, Bunga Rampai Kebijakan Hukum Pidana (Perkembangan Penyusunan Konsep KUHP Baru), Kencana Prenada Media Group, Jakarta.
Bohm, Robert M., dan Keith N. Haley, 2007, Introduction to Criminal Justice, McGraw-Hill, New York.

Fitzgerald, Maureen F., 2007, Legal Problem Solving : Reasoning, Research, and Writing, Edisi Keempat, LexisNexis, Canada.

ND,MuktiFajar, dan Yulianto Achmad,2007, Dualisme Penelitian Hukum, Fakultas Hukum Universitas Muhammadiyah, Yogyakarta.

R, Josias Simon, 2012, Budaya Penjara : Pemahaman dan Implementasi, Karya Putra Darwati, Bandung.

Rifai, Achmad, 2014, Narkoba di Balik Tembok Penjara, Aswaja Pressindo, Yogyakarta.

Simorangkir, J.C.T., dkk, 2000, Kamus Hukum, Sinar Grafika, Jakarta.

Soekanto, Soerjono, 2012, Pengantar Penelitian Hukum, Cet. III, Universitas Indonesia, Jakarta (UI-Press). , 2012, Faktor-Faktor yang Mempengaruhi Penegakan Hukum, Cet. XI PT RajaGrafindo Persada, Jakarta.

Poerwadarminta, W.J.S., 2007, Kamus Umum Bahasa Indonesia, Balai Pustaka, Jakarta.

\section{B. JURNAL ILMIAH}

Winandi, Woro, dan Indra Rukmana Lukito, Penjatuhan Pidana Mati Dalam Tindak Pidana Narkoba, Jurnal Hukum Vol. XIX, No. 19, Edisi Oktober 2010, Fakultas Hukum Universitas Narotama Surabaya. 
(UDAYANA MASTER LAW JOURNAL)

\section{PERATURAN PERUNDANG-}

\section{UNDANGAN}

Undang-Undang Republik Indonesia

Nomor 12 Tahun 1995 Tentang

Pemasyarakatan, Lembaran Negara

Republik Indonesia Tahun 1995

Nomor 77, Tambahan Lembaran

Negara Republik Indonesia Nomor 3614.

Undang-Undang Republik Indonesia Nomor 35 Tahun 2009 Tentang Narkotika, Lembaran Negara Republik Indonesia Tahun 2009 Nomor 143, Tambahan Lembaran Negara Republik Indonesia Nomor 5062.

\section{INTERNET}

SDP, Desember 2014, Data Terakhir Jumlah

Penghuni per-UPT Pada Kanwil BaliPeriode Desember 2014, tersedia di websitehttp://smslap.ditjenpas. go.id, diakses pada tanggal 8 Januari 2015.

Maiwa News, 2 Juli 2012, Bali Pasar Potensial Sindikat Narkoba Internasional, tersedia di websitehttp:// berita.maiwanews.comdiakses pada tanggal 14 Februari 2015. 